\title{
Historical perspectives of The American Association for Thoracic Surgery: G. Alexander Patterson
}

\author{
Stephanie H. Chang, MD, ${ }^{\mathrm{a}}$ Thomas A. D'Amico, MD, ${ }^{\mathrm{b}}$ and the American Association for Thoracic Surgery \\ Centennial Committee
}

George Alexander "Alec" Patterson (Figure 1), the 90th president of The American Association for Thoracic Surgery (AATS), was born at Royal Victoria Hospital in Montreal, Quebec, Canada, on January 21, 1949. The second of 6 children born to parents John and Joan Patterson, he grew up in Brockville, Ontario, Canada. In high school, he was the quarterback and captain of the football team, but his career aspirations were in medicine. He attended Queen's University as the Adiel Steacy Scholar, receiving his medical degree in 1974, and he remained at Queen's University for training in general surgery. Though he intended originally to specialize in orthopedic surgery and later in vascular surgery, Dr Patterson eventually focused on thoracic surgery because of the complexity of the clinical and investigative aspects and also because of the "tremendous mentors while [he was] training." After completing training in general surgery, he continued his training with fellowships in vascular surgery (1978-79), thoracic surgery research (1979-1980), and thoracic surgery (1980-1981) at the University of Toronto, followed by surgical intensive care and pulmonology (1981-1982) at Johns Hopkins University. Dr Patterson was thereafter certified by the Royal College of Physicians and Surgeons of Canada in general, thoracic, and vascular surgery.

In 1982, Dr Patterson joined the faculty in thoracic surgery at the University of Toronto under Dr F. Griffith Pearson, the 70th president of the AATS, and Dr Joel D. Cooper, the 84th president of the AATS. During his surgical training, Dr Patterson developed a strong interest in the developing field of lung transplantation, and he devoted much time and energy to making it a clinical reality. The development of a successful pulmonary transplant program had lagged for decades after the first unsuccessful attempt by Dr James Hardy in 1963.2

In 1983, at the University of Toronto, Dr Joel Cooper and his team, including Dr Patterson (Figure 2), performed the

\footnotetext{
From the Department of Surgery, ${ }^{\text {a }}$ Washington University School of Medicine, St Louis, Mo; and the Department of Surgery, ${ }^{\mathrm{b}}$ Duke University Medical Center, Durham, NC

Disclosures: Authors have nothing to disclose with regard to commercial support.

Received for publication Nov 12, 2013; accepted for publication Nov 22, 2013; available ahead of print Jan 31, 2014.

Address for reprints: Thomas A. D'Amico, MD, Duke University Medical Center, Box 3496, Duke South, White Zone, Room 3589, Durham, NC 27710 (E-mail: damic001@mc.duke.edu).

J Thorac Cardiovasc Surg 2014;148:2455-7

$0022-5223 / \$ 36.00$

Copyright (c) 2014 by The American Association for Thoracic Surgery

http://dx.doi.org/10.1016/j.jtcvs.2013.11.061
}

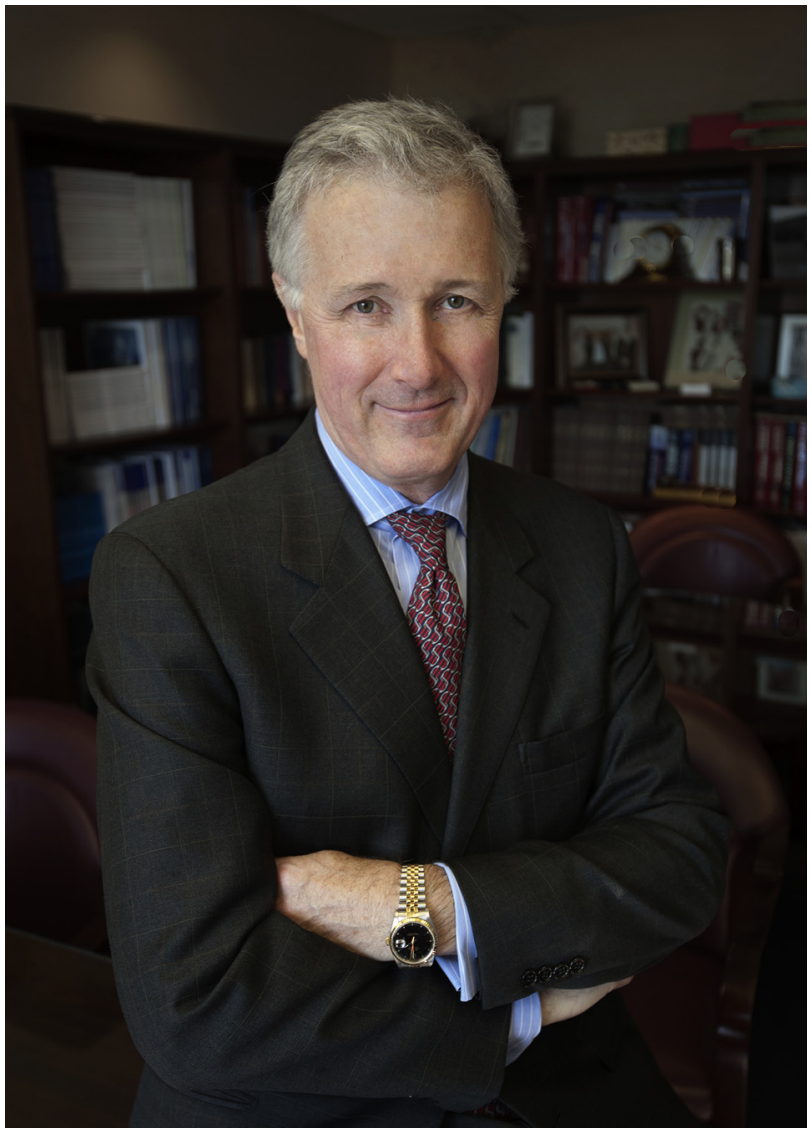

FIGURE 1. George Alexander Patterson, 90th president of The American Association for Thoracic Surgery.

first successful single-lung transplant, for pulmonary fibrosis. ${ }^{3}$ In 1986, Drs Patterson and Cooper performed the first successful double-lung transplant, for $\alpha$ - 1 antitrypsin deficiency. ${ }^{4}$ The success of the transplant program at the University of Toronto inspired the development of a transcendent technology: In 1985, only 5 lung transplants were performed internationally, whereas 2769 were performed in 2008. ${ }^{5}$ During his time in Toronto, Dr Patterson directed the most active lung transplant program in the world.

In 1991, Dr Patterson was recruited to Washington University in St Louis by Dr Cooper and Dr James L. Cox, 81st president of the AATS. In St Louis, he joined one of the first lung transplant programs in the United States at Barnes-Jewish Hospital. Under his direction, it has become one of the largest lung transplant programs and has performed more than 1300 pulmonary transplants. He was 


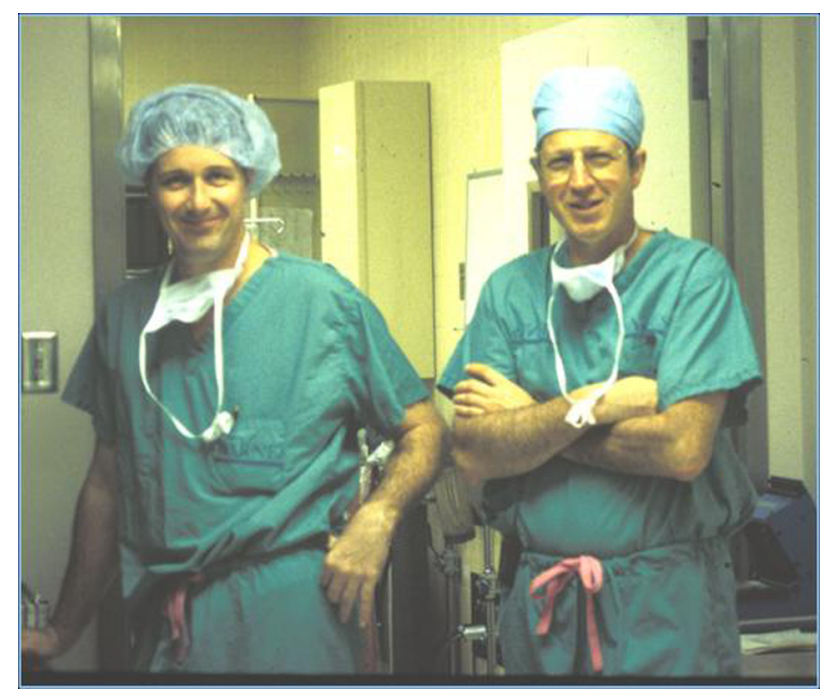

FIGURE 2. Operative team for the first successful single lung transplant, Drs Alec Patterson and Joel Cooper.

appointed as the Joseph C. Bancroft Professor of Surgery and the section head of general thoracic surgery in 1997. In 2005, he was appointed the Evarts A. Graham (10th president of the AATS) Professor of Surgery and the Chief of the Division of Cardiothoracic Surgery.

Dr Patterson's laboratory at Washington University has been continually funded since 1998 by the National Institutes of Health, and he has held more than 25 other major research grants. Dr Patterson has been a prolific investigator and successful mentor, with more than 400 publications, 70 book chapters, and 300 abstracts and presentations. In addition, he is the editor of 9 textbooks on thoracic surgery. He has served as visiting professor at 55 institutions worldwide. Dr Patterson recently was elected to become the next editor of the Annals of Thoracic Surgery.

His laboratory has investigated issues across the spectrum of general thoracic surgery, including technical aspects of lung transplantation, immunology, lung preservation, lung volume reduction, diaphragm function and transplantation, and many topics related to lung cancer. Moreover, his scientific productivity has attracted and involved innumerable students, residents, and junior faculty, propelling their careers in academic thoracic surgery as well. His work has also had an enduring international influence. Dr Patterson has hosted numerous Evarts A. Graham Memorial Traveling Fellows and has established important relationships with numerous international surgeons and programs.

Dr Patterson has received numerous honors, including the prestigious Medal in Surgery from the Royal College of Physicians and Surgeons of Canada in 1987 and the President's Lifetime Achievement Award from the BarnesJewish Hospital Foundation. He is a member or honorary member of nearly 40 professional associations worldwide

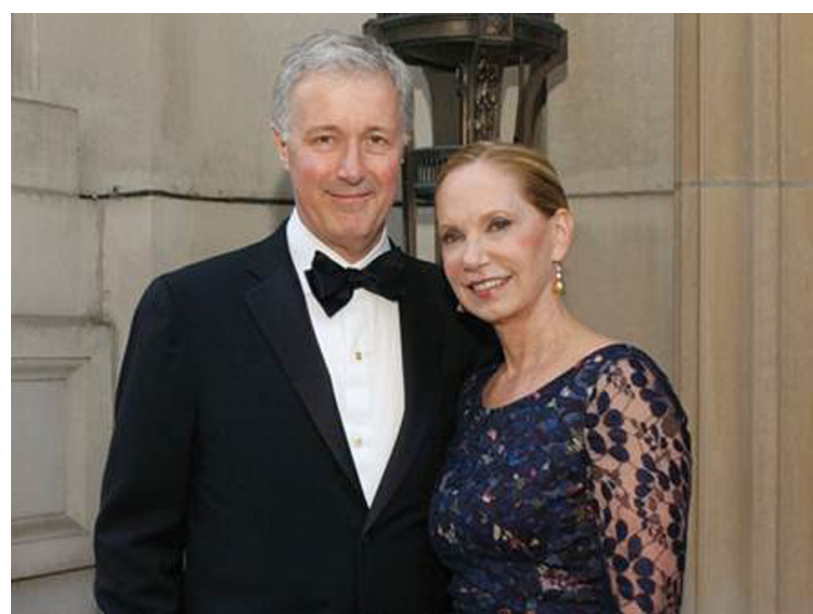

FIGURE 3. Dr Alec Patterson with his wife, Dr Susan Mackinnon, at the ceremony where Dr Mackinnon received the 2013 Jacobson Innovation Award from the American College of Surgeons. Photograph courtesy of Drs Patterson and Mackinnon.

and has held numerous important leadership positions. Dr Patterson has served as the president of the International Society of Heart and Lung Transplantation, president of the Thoracic Surgery Foundation for Research and Education, chair of the Lung Transplant Study Group, and chair of the Joint Council on Thoracic Surgery Education. He provided invaluable advice and was instrumental in establishing an important relationship between the European Society of Thoracic Surgery and the AATS.

Most notably, in 2009 he was inducted as the 90th president of the AATS. At the annual meeting in Toronto in 2010, Dr Patterson's address, "Non Solus-A Leadership Challenge," focused on the importance of scholarship and leadership in the field of thoracic surgery. He concluded with a plea to thoracic surgeons to honor the vision of the AATS ${ }^{6}$ : "We model excellence. The core values of the AATSleadership, scholarship, mentoring, and quality patient care-require a constant commitment to behavioral leadership."

At his presidential address in Toronto, Dr Patterson was surrounded by his family, an admirable model of mutual professional and personal support. At his side throughout his career has been his wife, Dr Susan Mackinnon (Figure 3), the Shoenberg Professor and Chief of Plastic and Reconstructive Surgery at Washington University in St Louis. Dr Mackinnon has had an equally prestigious career, receiving the Medal in Surgery from the Royal College of Physicians and Surgeons of Canada the year after Dr Patterson (1988) and serving as the president of the American Association of Hand Surgery in 2005 and the American Association of Plastic Surgeons in 2008. In addition, they have 4 children, whom Dr Patterson characterizes as his "greatest achievement" ": Lachlan, a renowned chef; Megan, assistant professor of orthopedics at the University of North Carolina; 
Brendan, a resident in orthopedics at the University of North Carolina; and Caitlan, holder of a master's degree and a fellowship in health administration.

In summary, Dr Patterson has personified the values of the AATS. Strongly influenced by his family and mentors (including several past presidents of the AATS), Dr Patterson has been instrumental in the development of lung transplantation, one of the most important technologies in thoracic surgery in the last 50 years, as well as fostering its most prolific clinical and scientific program. He has helped to transform the training in general thoracic surgery in the United States, improving its practice and outcomes. His international engagement has benefitted the careers of surgeons worldwide. Finally, he remains a role model for surgeons who aspire to leadership, scholarship, mentoring, and technical excellence, demonstrating that these goals can be achieved without compromising the values of virtue, integrity, or dignity. Dr Patterson was recently elected to become the next editor of the Annals of Thoracic Surgery.

\section{References}

1. Freeman E. Web exclusive: a match made in med school. St Louis Magazine. August 2007. Available at: http://www.stlmag.com/St-Louis-Magazine/August-2007/WebExclusive-A-Match-Made-in-Med-School/. Accessed August 21, 2013.

2. Hardy JD, Webb WR, Dalton ML Jr, Walker GR Jr. Lung homotransplantation in man. JAMA. 1963;186:1065-74.

3. Toronto Lung Transplant Group. Unilateral lung transplantation for pulmonary fibrosis. N Engl J Med. 1986;314:1140-5.

4. Patterson GA, Cooper JD, Dark JH, Jones MT. Experimental and clinical double lung transplantation. J Thorac Cardiovasc Surg. 1988;95:70-4.

5. Heart-lung transplantation. J Heart Lung Transplant. 2010;29:1083-141.

6. Patterson GA. Non Solus-a leadership challenge. J Thorac Cardiovasc Surg. 2010;140:495-502. 